\title{
当院における下肢切断術後の生命予後
}

\author{
吉 村 洋 一**多田弘史*宮本 雅 友* \\ 本 村 吾 朗* 増 田 陽 平*
}

\section{Prognosis after Amputation of the Lower Extremity in Our Hospital}

\author{
Yoichi Yoshimura*, Hiroshi Tada*, Masatomo Miyamoto*, \\ Goro Motomura*, and Yohei Masuda*
}

\begin{abstract}
当院にて 2000 年 1 月〜2005 年 12 月に行った下腿及び大腿切断術 55 例 56 肢について retrospective に 調査しその予後及びそれに関与する危険因子につき検討した。 また Kaplan・Meier 曲線を用いて生存率 を計算した。閉塞性動脈硬化症（ASO）や糖尿病（DM），虚血性心疾患，透析などの基礎疾患を合併し た患者が多く，調査時 37 人が死亡していた，義足による歩行が実用化したものは全体で 5 人であった. Kaplan-Meier 生存曲線では全体の 1 年生存率は $59.6 \%, 2$ 年生存率は $53.5 \%$ と諸家の報告と变わらなかっ たが，5年生存率は $17.9 \%$ と他の studyに較べかなり低かった。また透析患者，特にDM を合併した透 析患者群と虚血性心疾患患者群で生存率に有意差が出た。特に糖尿病性腎症の患者に対しては足病变の病 態把握のみならず生命予後をも考慮に入れた上で ADL よりもQOL を重視した切断高位選択などの慎重 な対応が必要と思われる。
\end{abstract}

From January 1st 2000 to December 31st 2005, we treated 55 patients, with 56 major amputations (Above Knee or Below Knee). We examined the prognosis of amputations of lower extrimity in our hospital. We also calculated the survival rate by using the Kaplan-Meier curve. Comorbidities included 49 cases of arteriosclerosis obliterans (ASO), 38 of diabetes (DM), 37 of ischemic heart diseases, and 26 of hemodialysis (HD) by chronic renal failure, etc. Thirty-seven patients had died during investigations, and only 5 patients reqained gait with the artificial leg. The overall 1-year survival rate was 59.6\% in the Kaplan-Meier survival curve, 2-year survival rate was 53.5\%, and 5-year survival rate was $17.9 \%$. There were significant differences in the ischemic heart disease group and dialysis group, especially in dialysis with diabetic patients. The one-year and two-year survival rates were equal to these reported in various studies, but the 5-year survival rate was considerably lower than these. Careful follow-up is important when selecting amputation level by considering patient's QOL more than ADL, especially for diabetic patients, after considering not only the conditions of the foot but also their life prognosis.

Key words : amputation (切断術), prognosis (予後), survival rate (生存率)

\section{は じめ に}

近年本邦でも末梢循環障害による下肢切断症例が増 加している．特に糖尿病性潰瘍や壊疽などの患者は通 常他の糖尿病（以下 DM）に伴う全身的合併症を有 しておりしばしば生命予後が不良である。当院ではそ の性格上循環器疾患を持った患者が多いが，DM や 閉塞性動脈硬化症（以下 ASO)などを合併した患者む 非常に多く，それら基礎疾患による血流障害患者に対 して下肢切断を余儀なくされる症例が増加している. 切断となった症例は決して生命予後が良好とは言えな
いが，本邦では下肢切断術後の生命予後やその他の合 併症の関連因子の影響の程度について検討した報告は 少ない。 そこで, 我々は当院にて下肢切断術を施行し た症例の経過を retrospective に調査し，生命予後に 関与する危険因子につき検討したので若干の考察を加 えて報告する.

\section{対象と方 法}

2000 年 1 月 1 日〜2005 年 12 月 31 日に行った下腿 及び大腿の初回切断術の 55 人 56 肢を対象とした。内 訳は女性 25 名, 男性 30 名, 切断時平均年齢は 70.2

* 小倉記念病院整形外科 Kokura Memorial Hospital, Kitakyusyu, Japan 
土11.6 歳（43〜98 歳）であった。術前合併症として は ASO 49 人 (89.1\%)が一番多く次いで DM 38 人 (69.1\%), 虚血性心疾患（以下 IHD）37人 (67.3\%), 慢性腎不全による透析（以下 HD） 26 人 (47.3\%), 脳血管疾患 13 人 $(23.6 \%)$ などであった. HD 患者 のうち糖尿病性腎症によるものは 23 人 (41.8\%) て あった，実に HD 患者の $88.5 \%$ が糖尿病性腎症であっ た.

な打切断部位の決定は壊疽の部位と, 皮膚の冷感や 色調などの所見とサーモグラフィーなどの検査結果を あとに, 最終的には術中の出血状態で判断した。

術後及び追跡時における調査方法は入院カルテにて 切断原因・治療内容・合併症などを調へ，退院後の転 帰，日常生活活動能力については電話により聞き取り 調査を行った，次いで死亡・生存の転帰により群分け し retrospective に解析し, 臨床的観察項目別に各軍 の Kaplan-Meier 法による生存率を Log-rank test を 用いて単変量比較した。 またその合併症と予後を調査・ 検討した。統計解析には StatMateIIII（株式会社アト ムス）を用い，危険率 $5 \%$ 以下を統計学的有意とした。

\section{結果}

2007 年 4 月の調査時点での転帰は，死亡者は 37 人 (67.3\%)，生存者は 18 人 (32.7\%) であった。生存 例の経過観察期間は平均 40.1 ヶ月（11８3 ヶ月）, 死亡例の術後生存期間は平均 17.8 ヶ月（3 日～59ヶ 月）であった。切断部位別では大腿切断 30 例, 下腿 切断 26 例で, 両側大腿切断が 1 例あった。左右の症 例はそれぞれ 28 肢ずつで同数であった。切断の原因 としては ASO または DM による血行障害が $89.1 \%$ （49 例）を占めていたが，急性動脈閉塞も 10.9\%（6 例）あった。最終的な ADL は車椅子 21 人 (38.2\%), 床上 29 人 $(52.7 \%)$ で，義足により歩行可能であっ たのは 5 人（9.1\%）に過ぎなかった。ここで最終的 な ADL とは死亡直前の ADL あるいは調查時におけ る ADL を表している.

次に Kaplan-Meier 生存曲線を用いた生存率につい て検討した，全体での生存曲線は図 1 で示すと抢りで あり，生存率は 1 年で $59.6 \% ， 2$ 年で $53.5 \% ， 5$ 年で 17.9\%であった（表 2).ささら各因子の生存率を比 較するため, Log-rank test による単变量解析を行っ たところ IHD 患者群，HD 患者群，とりわけ糖尿病 性腎症による HD 患者群で有意に生存率が低かった

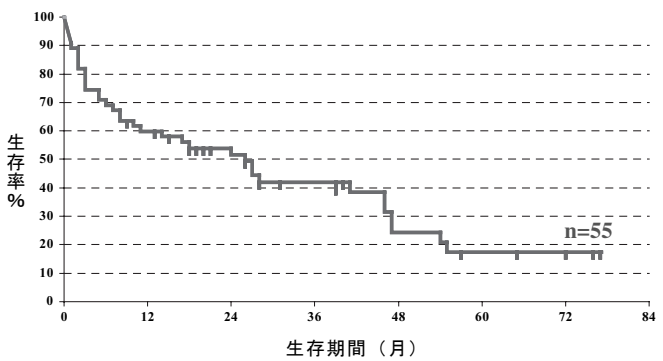

図 1 Kaplan-Meier 生存曲線（全体）

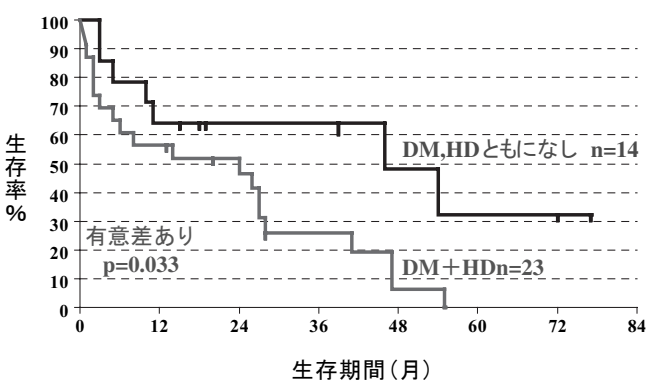

図 2 Kaplan-Meier 生存曲線（全体）

表 1 各因子の生存率比較

\begin{tabular}{|c|c|c|c|c|c|c|}
\hline & 観察数 & 死亡数 & 生存数 & 乙2乗値 & 有意差 & $\mathrm{p}$ 值 \\
\hline DMなし & 17 & 9 & 8 & \multirow{2}{*}{2.43} & \multirow{2}{*}{ なし } & \multirow{2}{*}{0.12} \\
\hline DM あり & 38 & 28 & 10 & & & \\
\hline
\end{tabular}

\begin{tabular}{|c|c|c|c|c|c|c|}
\hline & 観察数 & 死亡数 & 生存数 & 诔乗值 & 有意差 & $\mathrm{p}$ 值 \\
\hline 非 HD 患者 & 29 & 15 & 14 & \multirow{2}{*}{4.15} & \multirow{2}{*}{ あり } & \\
\hline HD 患者 & 26 & 22 & 4 & & & \\
\hline
\end{tabular}

\begin{tabular}{|c|c|c|c|c|c|c|}
\hline & 観察数 & 死亡数 & 生存数 & ○2乗値 & 有意差 & $\mathrm{p}$ 值 \\
\hline 心疾患なし & 18 & 9 & 9 & \multirow{2}{*}{4.26} & \multirow{2}{*}{ あり } & \multirow{2}{*}{0.039} \\
\hline 心疾患あり & 37 & 28 & 9 & & & \\
\hline
\end{tabular}

\begin{tabular}{c|c|c|c|c|c|c|c}
\hline & 観察数死亡数 & 生存数 & $\chi 2$ 乗値 & 有意差 & $\mathrm{p}$ 值 \\
\hline $\mathrm{HD}, \mathrm{DM}$ とむに & 14 & 7 & 7 & \multirow{2}{*}{4.54} & あり & 0.033 \\
\hline $\mathrm{HD}+\mathrm{DM}$ & 23 & 20 & 3 & & & \\
\hline
\end{tabular}

\begin{tabular}{|c|c|c|c|c|c|c|}
\hline & 観察数 & 死亡数 & 生存数 & 义2乗値 & 有意差 & $\mathrm{p}$ 值 \\
\hline BK & 26 & 16 & 10 & \multirow{2}{*}{0.23} & \multirow{2}{*}{ なし } & \multirow{2}{*}{0.63} \\
\hline $\mathrm{AK}$ & 29 & 21 & 8 & & & \\
\hline
\end{tabular}

（図 2，表 1)。な打 DM の有無，切断高位による生 存率の有意差はなかった（表 1 ）。 
表 2 合併症による生存率 (\%)

\begin{tabular}{l|l|l|l|l|l}
\hline \hline & 全体 & DM & HD & 心疾患 & DM+HD \\
\hline 1 年後 & 59.6 & 60 & 53.8 & 51.4 & 56.5 \\
\hline 2 年後 & 53.5 & 51.2 & 49.7 & 45.3 & 51.8 \\
\hline 3 年後 & 41 & 33.6 & 26 & 30.2 & 24.5 \\
\hline 4 年後 & 25.8 & 15.7 & 10.4 & 16.3 & 6.1 \\
\hline 5 年後 & 17.9 & 9.4 & 5.2 & 9.8 & 0 \\
\hline
\end{tabular}

考察

下肢切断術後の生命予後については，諸家の報 告 ${ }^{1) \sim 8)}$ によれば 1 年生存率が $47.0 \%$ 70.0\%，2 年 生存率が 30.3 62.0\% であり，壊疽患者の 5 年生存率 はわずか $38 \%$ との報告むある. 当院のデー夕では 1 , 2 年生存率は他施設と变わらないものの 5 年生存率は 他施設に較べてかなり低かった．やはり当院では病院 の性格上, 循環器疾患が多いのはさることながら,さ らには糖尿病・慢性腎不全・透析などの生命予後に大 きな影響を与える合併症を持った患者が非常に多く， 生命予後低下の原因の一つとなっていると考えられた. また手術時平均年齢が他施設よりも高かったことも生 命予後低下の一因となっているかも知れない.

下肢切断術後の予後不良因子として, Dossa ${ }^{1)}$ は $\mathrm{HD}$ 患者の下肢切断の生存率は 2 年で $50 \%$ 以下と予後 不良と報告している。また渡邊ら ${ }^{7)}$ は冠動脈病变の有 無と切断高位を上げている.この結果を受けて，及川 ら ${ }^{4)}$ は全身の動脈硬化の進行度が予後を反映する可能 性があるとして, 足背動脈触知可能群で有意に生存率 が高かったことを報告している。また Stratton $\mathrm{IM}^{5)} ら$ は予後不良因子について糖尿病に言及し, HbAlc が 1 \%低下するだけでハザード比が 43\%も減少すると述べて いる．当院でも糖尿病性腎症による透析患者では生存 率が有意に低いという結果であった。これらの結果か ら特に糖尿病における血糖コントロールをしっかりと 行うことが肝要と思われる. 今回の study ではDM の有無により生存率に有意差が出なかったが糖尿病合 併症例では壊疽による重症感染症の根絶を目的とした 切断が含まれておりまた逆にDM のない患者であ透
析をしている患者が多かったことなどが生存率に影響 したとも考えられる。また今回初期 12 ヶ月では DM の有無による生存率の差がほとんどなかったことから Log-rank テストで有意差が出にくかったことも一因 かも知れない.

また通常予後良好とされる BK 切断であるが，当院 で $\mathrm{AK}$ 切断, $\mathrm{BK}$ 切断で生存率に差がなかったという ことから考えると, 基礎疾患を多く合併しており全身 状態が悪い症例では手術浸襲を最小限に抑えざるを得 ない場合や再手術を危惧して手術を一期的に終える必 要がある場合は，十分に血流が保たれている，より高 位での切断あ考慮するべきであり，それにより救命率 も高くなると言えよう。透析患者, なかでも糖尿病性 腎症患者の場合は足病変の病態把握のみならず生命予 後をむ考慮に入れた上で ADL よりあ QOL を重視し た切断高位選択などの慎重な対応が必要と思われる.

\section{参 考 文 献}

1) Dossa, C. D., et al. : Results of lower extremity amputations in patients with end-stage renal disease. J. Vasc. Surg., 20 :14-19, 1994.

2）金本隆司，他：末梢循環障害による下肢切断例の検討. 中部整災誌, $46: 119-120,2003$.

3) Mckenna, M., et al. : The ratio of ankle and arm arterial pressure as an independent predictor of mortality. Atheroscalerosis, 87(2-3) : 119-128, 1991.

4）及川道雄, 他 : 透析患者の大腿または下腿切断の治療 成績の検討. 中部整災誌，45：631-632，2002.

5) Stratton, I. M., et al. : Association of glycemia with macrovascular and microvascular complications of type 2 diabetes. Br. Med. J., 321 : 405-413, 2000.

6) Taylor, L. M., Porter, J. M. : The clinical course of diabetics who require emergent foot surgery because of infection or ischemia. J. Basc. Surg., 6 : 454-459, 1987.

7）渡邊紳一郎，他：下肢壊死により患肢切断術を受けた 透析患者の生命的及び機能的予後. 中部リウマチ, 30(1) : 64-65, 1999.

8）八木啓輔, 他：下肢切断例の検討. 中四整会誌, 15(1)： 71-74, 2003. 